\section{World Birth Defects Day}

Previous articles published in this journal have underlined the health impact of congenital anomalies in Argentina. ${ }^{1-3}$ These are structural or functional alterations that are present at birth and have a significant medical or social impact. In Argentina, they are the second leading cause of infant mortality and a major cause of morbidity. Out of 6579 deaths of infants younger than one year old in 2017, $1864(28.3 \%)$ were caused to congenital anomalies. ${ }^{4}$ Between 2007 and 2016, infant mortality decreased approximately $27 \%$; however, such reduction varied depending on the specific cause. Perinatal deaths reduced $23.5 \%$, whereas those related to respiratory, infectious, and parasitic diseases or external causes decreased about $40 \%$. However, infant deaths caused by congenital anomalies reduced only $8.4 \%$ in the same period. ${ }^{5}$ Between November 2009 and December 2017, the National Registry of Congenital Anomalies (Red Nacional de Anomalias Congénitas de Argentina, RENAC), the national surveillance system for major structural anomalies, ${ }^{3}$ recorded 30678 cases out of 1937689 births, which accounted for a prevalence of $1.58 \%$ (confidence interval: 1.57-1.60). Extrapolating such prevalence to the 704609 births occurred in Argentina in 2017, approximately 11100 newborns with major congenital anomalies are expected per year.

The objective of this comment is to promote the World Birth Defects Day, an outreach strategy to encourage congenital anomalies research, prevention, and surveillance. Since 2013, every year, the World Birth Defects Day is celebrated on March $3^{\text {rd }}$. In 2019, more than 160 organizations participated in activities to raise global awareness. In Argentina, the RENAC, the Department for Maternal and Child Health of the Autonomous City of Buenos Aires, parent and patient associations, and health institutes were involved. The official World Birth Defects Day website (www.worldbirthdefectsday.org) details every participating organization and activities in relation to this day, and provides a toolkit of related resources and messages. These organizations seek to reach the population with messages in Spanish and English through Facebook, Twitter, and Instagram under the handle World BD Day.
Some relevant key messages are that birth defects cause a high morbidity and mortality and can be prevented, for example, with pregnancy planning, periconceptional intake of folic acid, preconceptional management of chronic conditions, rubella vaccination, and avoiding exposure to teratogenic agents during pregnancy, among other measures.

Pediatricians play a key role in the prevention of congenital anomalies. By interacting with families, they have a chance to provide information about primary prevention measures to avoid the occurrence of new cases.

Some of those measures are described below: ${ }^{6-8}$

- Planning for pregnancy.

- Prevention of maternal infections through rubella vaccination.

- Practice of good hygiene to prevent congenital infections.

- Cessation of exposure to known teratogenic agents: maternal smoking, alcohol and drug use.

- Adequate health care of women with diabetes and epilepsy since preconception.

- Counseling prior to the use of potentially harmful medication during pregnancy.

- Protection against mosquito bites: use of insect repellents, adequate clothing and, if possible, delaying any trip to areas with risk of Zika.

- Improvement of women's diet and promotion of folic acid supplementation $(400 \mathrm{mcg}$, starting in the preconceptional period).

- Reduced exposure to environmental pollutants.

- A healthy weight before pregnancy.

- Genetic counseling to families with a history of congenital anomalies.

If primary prevention fails or is not feasible, secondary and tertiary prevention measures focus on an early diagnosis and timely management of affected newborns, as well as on the prevention of complications, the establishment of a longer survival, and a better quality of life for patients. The early detection of congenital anomalies is a major role of pediatricians.

In the setting of the World Birth Defects Day, we invite our readers to join this celebration by participating in activities and spreading messages in relation to this major health problem. 
Boris Groisman, M.D., María P. Bidondo, M.D., Agustina Piola, Student, Ana L. Tellechea, M.D., Pablo Barbero, M.D., and Rosa Liascovich, M.D. National Registry of Congenital Anomalies (Red Nacional de Anomalías Congénitas de Argentina, RENAC), National Genetic Medicine Center (Centro Nacional de Genética Médica, CNGM), National Administration of Health Institutes and Labs (Administración Nacional de Laboratorios e Institutos de Salud, ANLIS), Ministry of Social Welfare and Health.

http:/ / dx.doi.org/10.5546/ aap.2019.eng.284

To cite: Groisman B, Bidondo MP, Piola A, Tellechea AL, et al. World Birth Defects Day. Arch Argent Pediatr 2019;117(5):284-285.

\section{REFERENCES}

1. De Sarasqueta P. Mortalidad infantil por malformaciones congénitas y prematurez en la Argentina: análisis de los criterios de reducibilidad. Arch Argent Pediatr. 2006; 104(2):153-8.

2. Bronberg R, AlfaroE, ChavesE, DipierriJ.Mortalidad infantil por malformaciones congénitas en Argentina: análisis del quinquenio 2002-2006. Arch Argent Pediatr. 2009; 107(3):20311.

3. Groisman B, Bidondo MP, Barbero P, Gili J, et al. RENAC: Registro Nacional de Anomalías Congénitas de Argentina. Arch Argent Pediatr. 2013; 111(6):484-94.

4. Ministerio de Salud de la Nación. Dirección de Estadísticas e Información en Salud. Anuario 2017. [Accessed on: April $\left.3^{\text {rd }}, 2019\right]$. Available at: http://www.deis.msal.gov.ar/ index.php/anuario-2017/.

5. Ministerio de Salud de la Nación. Regionalización de la atención perinatal en la Argentina: barreras, experiencias y avances en el proceso de regionalización perinatal. 2018. [Accessed on: April 4 $\left.{ }^{\text {th }}, 2019\right]$. Available at: http: / www. msal.gob.ar/images/stories/bes/graficos/0000001280cntregionalizacion-2018.pdf.

6. Taruscio D, Mantovani A, Carbone P, Barisic I, et al. Primary prevention of congenital anomalies: recommendable, feasible and achievable. Public Health Genomics. 2015; 18(3):184-91.

7. BrentRL. Counseling women and men regarding exposures to reproductive and developmental toxicants before conception or women during pregnancy. Semin Fetal Neonatal Med. 2014; 19(3):139-52.

8. Organización Mundial de la Salud (OMS). Defectos Congénitos: informe de la secretaría. 63. ${ }^{a}$ Asamblea Mundial de la Salud. Ginebra, 2010. [Accessed on: April $\left.4^{\text {th }}, 2019\right]$. Available at: https://apps.who. int / iris / bitstream/handle / 10665/4849/A63_10-sp. pdf? sequence $=1 \&$ isAllowed $=y$. 